\title{
Examining Driving Forces of SHRM Practices Promoting Organisation Effectiveness
}

\section{Sathya Moorthi, S.B. Inayath Ahamed}

\begin{abstract}
The aim of this study is to find out the factors underlying a SHRM practice which promotes organization effectiveness by studying the implication and existence of SHRM practices in the firm and analyzing the impact of HR strategy on achieving organizational effectiveness in the firm. Both primary and secondary data was used in the process of carrying out the study. In order to collect the primary data, a well-formulated questionnaire was circulated and personal interviews were carried out with the employees in the firm. Secondary data was collected from the firm's employee manual, HRM reports, and HR journals. All the 30 (sample size) officials from top management and few line managers from the firm (stationed at Tuticorin) are the respondents for the study. Judgmental sampling was used. Percentage and Correlation method was used for the analysis. Forty-three percent employees feel that the CSR activities carried out in the firm has been influenced by the incorporation of SHRM in the management. More attention can be given on carrying out CSR activities effectively. Job rotation and flexible schedules can be carried out to improve the employees' progress. The management should ensure that the functional managers should work in close co-ordination with the HR managers rather than allowing it to work isolated. This will ensure that, the HR practices are carried out without deviating from the HRM policy of the company.
\end{abstract}

Keywords: Driving Forces, Effectiveness, HR strategy, SHRM practices

\section{INTRODUCTION}

SHRM is concerned with how far the human resource management is fully associated and concerned with the strategy and the strategic needs of the firm. Human resource policies involve both across policy areas and across various levels in the organization. Human resource framework of the firm as a part of organization's architecture is a calculated mix of structure, system, rewards, processes, people, styles, skills, and shared values according to Mckinsey-7 Ss. Human resource framework when done properly of the firm can results in increased financial performance.

Each organization has its own way of maximizing profits with the aid of available resources. This research is done in order to explore the existing practices in the firm and is directed towards explaining and understanding of the relationship between human resources management practices, policies and firm performance.

\section{STATEMENT OF THE PROBLEM}

The study is aimed at addressing how the HR policies and systems designed in the firm so that it supports the management.

\section{Revised Manuscript Received on December 09, 2019.}

Mr.V. Sathya Moorthi*, Research Scholar, Department of Business Administration, Kalasalingam Academy of Research and Education, Krishnan Koil, sathyamoorthi.v@klu.ac.in.

Dr.S.B. Inayath Ahamed, Assistant Professor, Department of Business Administration, Kalasalingam Academy of Research and Education, Krishnan Koil, inayathahamed@klu.ac.in
The difference in performance after employing SHRM practices. The relationship between variables related to organizational capabilities and effect of SHRM strategies employed in the firm.

\section{OBJECTIVES OF THE STUDY}

The aim of this study is to find out the factors underlying a SHRM practice which promotes organization effectiveness by studying the implication and existence of SHRM practices in the firm and analyzing the impact of HR strategy on achieving organizational effectiveness in the firm.

\section{METHODOLOGY}

Both primary and secondary data was used in the process of carrying out the study. In order to collect the primary data, a well-formulated questionnaire was circulated and personal interviews were carried out with the employees in the firm. Secondary data was collected from the firm's employee manual, HRM reports, and HR journals. All the 30 (sample size)officials from top management and few line managers from the firm (stationed at Tuticorin) are the respondents for the study. Judgemental sampling was used. Percentage and Correlation method was used for the analysis.

\section{RESULTS OF THE STUDY}

The results of the study are split into three main parts where the performance of the firm are studied using the business indicators which are the firm's financial performance, the social performance of the firm, employee performance and the customer's performance.

TABLE I: DEMOGRAPHIC PROFILE OF THE SAMPLE EMPLOYEE

\begin{tabular}{|c|c|c|c|c|}
\hline CATEGORY & $\begin{array}{c}\text { Frequen } \\
\text { cy }\end{array}$ & $\begin{array}{c}\text { Perc } \\
\text { ent }\end{array}$ & $\begin{array}{c}\text { Valid } \\
\text { Percent }\end{array}$ & $\begin{array}{c}\text { Cumul } \\
\text { ative } \\
\text { Perc } \\
\text { ent }\end{array}$ \\
\hline less than 25 & 1 & 3.3 & 3.3 & 3.3 \\
\hline 26 to 30 & 7 & 23.3 & 23.3 & 26.7 \\
\hline 31 to 40 & 13 & 43.3 & 43.3 & 70.0 \\
\hline 41 to 50 & 6 & 20.0 & 20.0 & 90.0 \\
\hline 51 and above & 3 & 10.0 & 10.0 & 100.0 \\
\hline \hline
\end{tabular}

Category- educational qualification

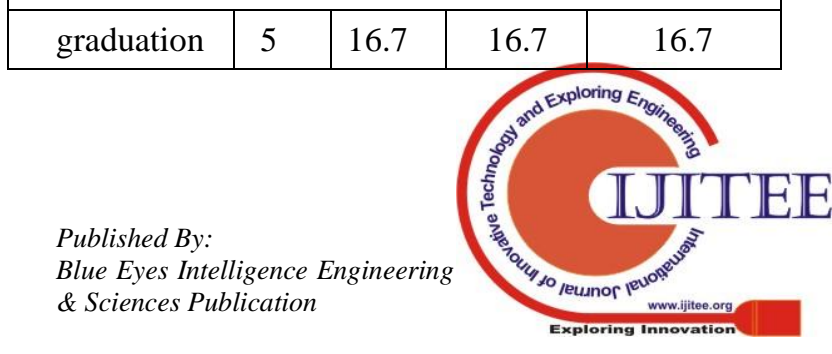




\begin{tabular}{|c|l|l|l|l|}
\hline $\begin{array}{c}\text { post } \\
\text { graduation }\end{array}$ & 21 & 70.0 & 70.0 & 86.7 \\
\hline $\begin{array}{c}\text { technical } \\
\text { qualification }\end{array}$ & 4 & 13.3 & 13.3 & 100.0 \\
\hline \multicolumn{5}{|c|}{ Category length of service } \\
\hline less than 5 & 6 & 20.0 & 20.0 & 20.0 \\
\hline 6 to 10 & 3 & 10.0 & 10.0 & 30.0 \\
\hline 11 to 15 & 9 & 30.0 & 30.0 & 60.0 \\
\hline 16 to 20 & 4 & 13.3 & 13.3 & 73.3 \\
\hline
\end{tabular}

Source: Survey Data

The above table shows the demographic profile of the respondents. It can be very well observed that the number of female respondents in the firm is very less. Steps can be taken to maintain the ratio between male and female.

TABLE II: IMPACT OF SHRM ON FIRM'S FINANCIAL PERFORMANCE

\begin{tabular}{|l|l|c|c|}
\hline \multicolumn{4}{|c|}{ Correlations } \\
\hline & \multicolumn{1}{|c|}{$\begin{array}{c}\text { Firm's } \\
\text { financial } \\
\text { performanc } \\
\text { e }\end{array}$} & $\begin{array}{c}\text { HR } \\
\text { strategie } \\
\text { s }\end{array}$ \\
\hline $\begin{array}{l}\text { Firm's } \\
\text { financial } \\
\text { performance }\end{array}$ & $\begin{array}{l}\text { Pearson } \\
\text { Correlation }\end{array}$ & 1 & $.465^{* *}$ \\
\hline & Sig. (2-tailed) & & .010 \\
\hline HR & N & 30 & 30 \\
\hline strategies & Pearson & $.465^{* *}$ & 1 \\
\hline & Correlation & & \\
\hline & Sig. (2-tailed) & .010 & \\
\hline & N & 30 & 30 \\
\hline
\end{tabular}

Correlation is carried out in order to find the relation between the firm's performance and the HR strategies. Around, thirty percent of respondents 'strongly adhere' to this fact that obtaining superior client focus is the important attribute which has helped the organization to stay successful in the business for a extended period of time. This should be given close supervision as it is responsible in improving the margin of the profits.

\section{TABLE III: IMPACT OF SHRM ON CUSTOMER'S PERFORMANCE}

\begin{tabular}{|c|c|c|c|}
\hline \multicolumn{3}{|c|}{ Correlations } \\
\hline & & $\begin{array}{c}\text { Customer' } \\
\mathrm{s} \\
\text { Performan } \\
\text { ce }\end{array}$ & $\begin{array}{c}\text { HR } \\
\text { Strategie } \\
\mathrm{s}\end{array}$ \\
\hline $\begin{array}{c}\text { Customer's } \\
\text { Performance }\end{array}$ & $\begin{array}{c}\text { Pearson } \\
\text { Correlation }\end{array}$ & 1 & $.405^{* *}$ \\
\cline { 2 - 4 } & & \\
\hline
\end{tabular}

\begin{tabular}{|c|c|c|c|}
\cline { 2 - 4 } & Sig. (2-tailed) & & .248 \\
\cline { 2 - 4 } & $\mathrm{N}$ & 30 & 30 \\
\hline HR Strategies & $\begin{array}{c}\text { Pearson } \\
\text { Correlation }\end{array}$ & $.405^{* *}$ & 1 \\
\cline { 2 - 4 } & Sig. (2-tailed) & .248 & \\
\cline { 2 - 4 } & $\mathrm{N}$ & 30 & 30 \\
\hline
\end{tabular}

The same was done between the other business indicators like customer's performance, social performance and employee performance. With the help of the analysis, it was observed that in the concerned firm, there was relation between the various business indicators and the HR strategies.

The concerned organization considers strategic human resource management as an integral component for the functioning. The practices are designed in such a way that sustainable competitive advantage is achieved. The HR capabilities are developed in such a way that it is not possible for the potential competitors to emulate it. The HR policies, practices and programme are conveniently incorporated in order to achieve the corporate objectives.

In order to attain more benefits, the management should ensure that the functional managers should work in close co-ordination with the HR managers rather than allowing it to work isolated. This means that the senior HR managers needs to work as a team and be a strategic partner with line managers in order to liaison between the management and employees in lower cadre .This will ensure that, these HR practices are carried out without deviating from the HRM policy.

\section{CONCLUSION}

The role of the HR department in the firm is in close conformance with the concepts of Ulrich model which was formulated by Dave Ulrich. According to Dave, in big organisations the role of HR has to be inclusive of the attributes like a strategic partner and change agent. This holds good for the firm and it can be witnessed from the findings of the study carried out. With the aid of close monitoring it is very evident that the firm functions on the basis on the The Entrepreneurial Start-up and employs the Ulrich model for its administration. This study emphasizes the importance of aligning the workforce with the strategy rather than the conventional method.

\section{REFERENCE}

1. Frase, M. J., "Smart Selections," HR Magazine, December 2007.

2. Armstrong, Michael, (2008). Strategic Human Resource Management: A Guide to Action, 4th Edition, Kogan Page, London, p.11.

3. Porter, Michael E., (1985). Competitive Advantage, Creating and Sustaining Superior Performance, The Free Press, USA, p.38.

4. Wernerfelt, Birger, (1984). "A Resource- based View of the Firm", Strategic Management Journal, Vol.5, p.172, pp.171- 180.

5. Lado, Augustine A., Wilson, Mary C., (1994). "Human Resource Systems And Sustained Competitive Advantage: A CompetencyBased Perspective", Academy of Management Review, Vol. 19. No. 4, p.699, pp.699-727. 
6. Fitz-enz, Jac, (2000). The ROI of Human Capital: Measuring the Economic Value of Employee Performance, American Management Association, USA, p.1.

7. Pfeffer, Jeffrey, (1994). Competitive Advantage Through People: Unleashing The Power of Workforce, Harvard Business School, USA, p.57. Esra NEMLİ ÇALIŞKAN 115

8. Wright, Patrick M., Dunford, Benjamin B., Snell, Scott A., (2007). "Human Resources and Resource-Based View of The Firm", in: Randall S. Schuler, Susan E. Jackson, Strategic Human Resource Management, 2nd Edition, Blackwell, USA, p.76.

9. Schuler, Randall S., Jackson, Susan E., (2007). Strategic Human Resource Management, Blackwell Publishing, USA, , p.xiii.

\section{AUTHORS PROFILE}

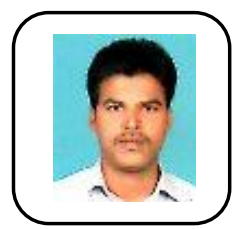

V.Sathya Moorthi, Completed graduation B.Sc., in special maths in The American College, Madurai and post Graduate MBA in Kalasalingam University, Currently a research scholar in kalasalingam university in the department of management. I have 2 years of research experience and 7 years of teaching experience from various colleges and university. I have specialized $\mathrm{n}$ human resource management and marketing.

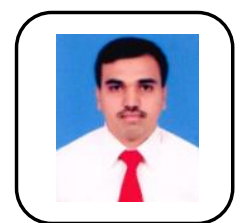

Dr.S.B. Inayath Ahamed, Completed graduation BE (EEE) in Sona College of Technology and post graduation MBA in BS Rahuman University. He has completed his Doctorate in periya university specialized in Marketing. He posses 3 years of teaching experience. He has published 17 papers in various national and international journal. 